\title{
If Derrida Had Played Football
}

Allan C. Hutchinson

Osgoode Hall Law School of York University, ahutchinson@osgoode.yorku.ca

Source Publication:

German Law Journal. Volume 6, Issue 1 (2005), p. 53-64.

Follow this and additional works at: https://digitalcommons.osgoode.yorku.ca/scholarly_works (c) (i) (9)

This work is licensed under a Creative Commons Attribution-Noncommercial-No Derivative Works 4.0 License.

\section{Recommended Citation}

Hutchinson, Allan C. "If Derrida Had Played Football." German Law Journal 6.1 (2005): 53-64.

This Article is brought to you for free and open access by the Faculty Scholarship at Osgoode Digital Commons. It has been accepted for inclusion in Articles \& Book Chapters by an authorized administrator of Osgoode Digital Commons. 


\title{
If Derrida Had Played Football
}

\author{
By Allan C. Hutchinson*
}

"Is football a matter of life and death?

No, it's much more important than that."

- Bill Shankly

In a candid interview in 1991, when he was 60, Jacques Derrida let the cat out of the bag. For all his academic achievements and popular acclaim, his abiding dream for himself remained that of his youth "becoming a professional footballer." 1 In this mere aside, Derrida revealed as much about himself as both philosopher and person (if they can be separated) as in almost all his voluminous writings, speeches, reviews, and interviews. How fitting, therefore, that this passing remark should take us from the expressive margin into the subversive heart of this man of thought and reveal him as a frustrated man of action; the philosophical life was only a consolation for a more fulfilled life as sporting hero. Yet, in so many ways, so much can be learned and understood about the Derridean oeuvre by treating its author as a footballer, as someone who plied his trade on the fields of sporting endeavour than in the classrooms and libraries of the world. Indeed, if Derrida had played football, both philosophy and life might have been the better for it. Not because he would have spared the world his philosophical interrogations, but because he might have made even more of an impression on the sensibilities and senses of his times. It is as a footballer of attacking flair, not as an intellectual of defensive legend, that I will remember Derrida best. While it is hard to imagine the suave Derrida in the garishly-coloured synthetic shirt of his favourite team with a number " 7 " and "Derrida" emblazoned on the back, there is a genuine excitement at the prospect of him tantalising and tormenting the opposition in his own version of "the beautiful game." He knew that those who knew nothing of football knew nothing of life.

\footnotetext{
"Osgoode Hall Law School, York University, Toronto.

${ }^{1}$ G. BENNINGTON, JACQUES DERRIDA 71 (1991).
} 
I.

Everyone needs a foil, someone or some style against which they can develop and display their own talents. For Derrida, Plato and his followers was the epitome of all that was wrong with football. Plato wanted to find the perfect game, the game of games, the one true and only real way to play the game, a God's eye-view of the game. His mission was to distinguish the necessary from the contingent, the universal from the particular, and the conceptual from the concrete. Plato's belief was that there was one Game of games and one way to play that Game. Although he talked of "wonder," he was driven by the fear that, without such an ideal possibility, the show would be over and that anything could and would go all the ways of playing the game were as good as any other way of playing the game and there would be no way to criticise or approve of such ways of playing the game in any general or objective way. Plato cast an appalling shadow over the game, its coaching and its performance. Derrida was determined to change all that.

For Derrida, the problem with Plato's approach was the failure to resist the temptation to divide the world up into categories. To understand and control the world, Platonists employ a set of rigid distinctions that are treated as natural and obvious, such as objective/subjective, reason/emotion or mind/body. Indeed, the "natural" was a particularly treasured category to be contrasted with the contrived or constructed. This means that any coherent and cogent account of fixed meaning and grounded knowledge must not only explain the precise and stable relation between these oppositions, but also find a way of talking about them that is itself precise and stable. In a signature move that has underpinned and distracted Western thinking, philosophers claim to do this by privileging one over the other and granting metaphysical authority to it -- objective over subjective, reason over emotion, and mind over body. And, of course, this has had implications for what we value in people and how we go about organising the world. For instance, we tend to associate objectivity, rationality and intellectuality with sound thinking in contrast to a less valued emphasis on subjectivity, emotions and physical instinct.

To its eternal loss, much of the thinking and practice in football has been influenced by this Platonic strategy. However, in the Twentieth century, several different approaches to the importance of games and their relation to play have begun to assert themselves. Influenced by the formidable insights of those German Übermenschen, Friedrich Nietzsche (who subscribed to the "no pain, no gain" school of endeavour) and Martin Heidegger (who never used a simple or easy phrase when a more complicated or obscure one would do), a number of European theorists -- Ludwig Wittgenstein, Hans-Georg Gadamer, and Johan Huizinga, to mention but a few -- sought to rehabilitate the neglected idea of "play" and to reimagine football in its suggestive terms. Their basic line was that football, like all 
games, was a form of play; games were rule-based, but they allowed for play and choice within them. Moreover, they insisted that play was never "mere play," that its significance was not to be under-rated because play, in its game and non-game form, offered a subversive challenge to stilted values and rational styles of understanding. At its most grandiose, these philosophical play-masters wanted to treat all human activity as being part of the Great Game of Life and World-Play; the rules and goals were never fully established and were actually part of the game itself. In the Nietzschean sense, history consisted of a violent, arbitrary and ecstatic play of forces in which man is both player and plaything: life was an exuberant match of football.

Derrida picked up on this tradition. While his work owes much to the legacy of Friedrich Nietzsche, it neither begins with nor ends with him. Although Nietzsche had found the right tree, his barking did little to help his cause. Seemingly preferring excess in all things, Nietzsche went very close to reinforcing the hold of absolute truth by celebrating its flip-side -- nihilism. He inverted Plato and emphasised the Dionysian madness in which there is no good or bad, only the will to power. Derrida took up this theme that life is less a pilgrimage, as Plato thought, and more of a carnival, as Nietzsche suggested. But Derrida introduced a rigour and discipline to the Nietzschean insight. While embracing the idea that there are no objective foundations to knowledge or living, he insisted that this does not render all knowledge illusory, turn all truths into falsehoods, throw all order into chaos, or reveal all objectivity as sham. Being a believer in an open and fluid game, Derrida did not pin his hopes on finding an ultimate foundation and guarantor of knowledge, truth and the rest, but on keeping the game going so that different ideas of knowledge, truth and the rest might be tried and tested. Footballers, like philosophers, need to have passion as well as intellect; they need to be a part of the game, not apart from it.

An Algerian by birth, Derrida became the enfant terrible of the French intellectual team. His views tended to polarise debate around the notion of play and life generally. Embraced by some as a sporting guru of genius, others (particularly the stuffy English strongholds of traditional philosophy) have decried him as the worst kind of athletic poseur. When Derrida was awarded an honorary degree from Cambridge United (which was, incidentally, Wittgenstein's favourite team) in 1992, his critics were sufficiently well-organised and influential that he was denied this accolade:

M. Derrida describes himself as a [footballer], and his [performances] do indeed bear some marks of ... that discipline, ... [but] $\mathrm{M}$. Derrida's work does not meet accepted 
standards of clarity and rigour; ... he seems to us to have come close to making a career out of what we regard as translating into the [sporting] sphere tricks and gimmicks similar to those of the Dadaists. ${ }^{2}$

In these words are the usual motifs of inclusive and exclusive, serious and playful, and genuine and gimmicky that Derrida spent much of his life challenging. Indeed, this rejection makes many of the points and reveals much of the insecurity which his career was so cannily able to underscore. Indeed, insofar as it is possible to claim to have threaded a way through all the nuanced wisdom and exaggerated nonsense of his difficult fixtures, Derrida might well be a kind of philosophical Maradona of the footballing consciousness, a crazy combination of incomparable technical skills, unpredictable temperament and exquisite eye for the main chance who dazzles and deconstructs with his audacious fakes and feints, mazy dribbling and his deadly finish. Pinning down Derrida is no less a hopeless challenge than it was trying to mark Maradona out of the game.

For Derrida, human life and history were to be treated, like football, as one big playground that has no inherent design or natural purpose. There have been imposed a whole set of social games that privilege certain kinds of activities and ideas; they channel the free-play of human interaction, beliefs and practices into arbitrary structures and patterns. In contrast to traditional thinking, Derrida's deconstructive critique goes behind those hierarchical dichotomies -objective/subjective, reason/emotion and mind/body and shows that they have a history and are far from natural or obvious. Within such an approach, play is treated not so much as irrational, but more as part of what it means to be rational: there is no Reason for settling arguments about reason that are not themselves part of the game of reasoning. It is less a matter of either/or and more one of both/and. The ambition is not to privilege play at the expense of structure or to value the subjective over the objective; those that simply want to invert the relation and privilege play over structure remain trapped within the very Platonic system they claim to subvert and reject. Meanings are found in the un-grounded and multiple "play of differences" between the opposites. ${ }^{3}$ All understanding is interpretive and, therefore, playful -- there is no neutral or disinterested apprehension of objective authority. Moreover, the element of play can never be repressed or disciplined

\footnotetext{
2 Barry Smith et al., Letter, The Times (London), 9 May 1992.

${ }^{3}$ J. DERRIDA, MARGINS OF PHILOSOPHY 1-28 (A. Bass trans. 1982) and POSITIONS 39-49 (A. Bass trans. 1982).
} 
entirely: it continually reasserts itself to disrupt and reconfigure the way that different games are played. In seeking to express itself, play is not pursuing some ultimate goal, but is simply opening up the game of life so that new games with new players can move in from the margins. There is nothing beyond play, but more play; there is no Game of games that can save us or satisfy us. Nor is there any Play of plays; there are only more and different games to play in and be played.

Whether playing or talking about playing, Derrida emphasised that football puts into question all kinds of issues about the way to play the game of life. And, of course, issues of legality, ethics, politics and moral judgment in each person's life and daily social practices inform the performance and understanding of football. In the academic jargon of the day, football is a "social text" upon which are inscribed signs from other social texts and experiences: football is a rare blend of military battle, religious ritual, class warfare, sexual encounter, cathartic release, and much else besides. Understood as textual artifices, football games, although ostensibly rule-based and rule-structured activities, are never quite or only what they seem; there is more to them than meets the eye and what meets the eye is filtered through a host of interpretive filters. Football can be treated as a social practice or performance that invites interpretation and obtains its meaning through its production, positioning and role as a cultural artefact. While it has no core or any enduring essence, its followers make frequent appeals to some transcendent archetype or imagined version of the game to understand and assess its intrinsic meaning as well as its broader import. Any understanding of what it really means to play the game is constantly evolving and changing. In other words, the heart of football is the inconclusive and passionate game over what it means to play the game.

Most importantly, Derrida was adamant that football, like all other games, must be understood as being played out in that historical and social space that is defined by the tension between the game as "game" and the "game" as an embodiment of cultural lessons and broader messages. At different times and in different ways, football is both a finite and infinite game or, to put it more another way, finite episodes of football take place within the infinite possibilities of Football. In each game, there is a result and, over the course of a season, there are winners and losers: one team is able to claim victory over others in competitions and championships of local and national play. Nevertheless, the broader game of football and life continues unabated; the result in the finite occasion of a particular game is one strategic episode whose general performance becomes open to revision and reformulation at the very moment that it brings to a close that particular instance of footballing play. Accordingly, as a cultural drama, football captures the concentrated fizz that is life itself; football's text is woven in and through life's texture. In every kick, every header, every tackle, every half, every shot, every injury, 
every goal, every miss, we can see, know, understand and give meaning not only to "the game," but to our lives in all its complexity and possibility.

As showcased by Derrida, football, like life, is an infinitely variable process in which there is never any ultimate victory or performance, but only the repeated and unrepeatable working of the space between order and chaos, freedom and constraint, acceptance and possibility, and permanence and contingency. Being a game of infinite possibilities, football only has the present shape and style that it has because its players and fans are largely satisfied with its present practice or are unwilling to change it. But there is nothing about football today that should be thought of as The Way Football Really Is. At best, it only amounts to a contingent understanding of what it means to play the game. Efforts to isolate and define the essence of Football are irresistible, but irresolvable.

Of course, this means that what passes for good football or play in the future might bear little or no resemblance to its present or past understanding; it is not that "anything will go," but that "anything might go." Moreover, what counts as good football will depend upon what people are persuaded to accept as being a proper or appropriate way to play the game: it is a matter of social fact and popular persuasion, not official edict and technical analysis. As an activity that is always beyond absolute determination and never fully finished, football not only passively allows, but also actively encourages transformative and disruptive acts because, without them, the game risks paralysis and irrelevance. As another French sage rather opaquely put it, "the novelty of the unexpected 'move' ... can supply the system with that increased performativity it forever demands and consumes." 4 And Derrida was a past master at the novel and unexpected. Like the best of footballers, he was at his most dangerous and effective when he seemed to be most contained and controlled. It was his ability to conjure up the mysterious out of the familiar (as much as the familiar out of the mysterious) which was his calling-card. Yet he knew that too much of the unpredictable was predictable and so he could do the expected in an entirely exceptional way.

\section{II.}

The quality of greatness, in footballing or philosophising, is never fixed; it is a contingent and contested notion. All great players not only possesses special qualities, but also put their unique spin on what counts as great. What it means to be a great player is part of the infinite and contingent game over what it means to

\footnotetext{
${ }^{4}$ J-F. LYOTARD, THE POSTMODERN CONDITION: A REPORT ON KNOWLEDGE 15 (1984). See also J-F LyOTARD AND J-L THEBAUD, JUST GAMING 28, 43 (1985).
} 
play the game. The hallmark of great players is not simply their ability to beat every one at their own game: it is the capacity to envision and dictate a different game to be played. Greatness is to be found in the inestimable genius to improvise, experiment with and transform conventional standards for playing law's infinite game. For such artists (because that is what they are), the best accolades are earned not for their technical prowess, but their capacity to reveal possibilities that the rest of the football community have not even seen or thought possible. By making novel moves, they play the game of football and life as much by playing with the game as playing within it. At its most audacious, this style of play demands an almost daredevilish approach, not only a willingness to chance spectacular failure, but also the courage to court it in the pursuit of the greater glory of the game itself; it is a precarious and potent recipe for greatness that only a few can even aspire to, let alone successfully achieve. In short, they are great players in and on their own terms; they surpass existing standards as they transgress and transform them. By my reckoning, Derrida was not only a great player, but a great player at the game of defining greatness.

Of course, Derrida owes some of the mystique that surrounds his work to its opaque, obscure and, frankly, often incomprehensible nature; he was an enigmatic player who managed to be both conservative and revolutionary as well as backward-looking and non-traditional. Yet, for all that, his style of play had the mark of greatness in it. Indeed, there is much in a Derrida's performance that resonates with the artistry and career of Maradona. Like Maradona, Derrida was his own player and played his own game and controversy seemed likely to follow him wherever he went; he had good games and bad games. His skills were extravagant and his global effect on the world could not be ignored in his relatively short career. However, perhaps the one modern player that best epitomises the style and achievement of Derrida is his fellow Frenchman, Eric Cantona. While playing in and against some of the most established teams, they both took on something of the role of the "outsider." In this, they both resembled Camus' eponymous rebel, the outsider Meursault, who refused to submit to conditions and circumstances that stifle humanity and deprive them of their justified and rebellious destiny: "rebellion cannot exist without the feeling that somewhere, in some way, you are justified." 5

A self-styled Gaelic savant, Cantona cultivated the weighty persona of the outsider and bad boy. In a career arc that had equal measure of footballing genius and

\footnotetext{
`A. CAMUS, THE OUTSIDER 19 (J. Laredo trans. 1982). Sadly, Maradona will be remembered as much for his disputed "Hand of God" goal in the World Cup encounter with England in 1986 and his banishment from the sport for drug-use as for his unique talent. While Derrida had his moments, they were more illjudged than illicit.
} 
disciplinary transgression, philosopher-king Eric played football like he played life: he was unpredictably talented and talentedly unpredictable. He built up a moody reputation that served him well in his dealings with defenders on the field as well as his detractors off it. Such was his skill at surrounding himself with mystery that he was able to get away with the obvious and straightforward as if he had done the most unexpected and feigned of moves. For some, his demeanour was more psychotic than philosophic, his displays of footballing virtuosity more artifice than honest, and his petulance more definitive than distracting. Nevertheless, his influence on the English game is surely undisputed; he introduced a continental element to the English style of play whose transformative effect is likely to continue for decades to come. Yet, like Derrida's, Cantona's career was haunted by a notorious incident which both blighted and blessed his reputation.

After being sent off in a league game, Cantona dived into the stands to assault a racially-abusive fan. He was duly suspended from playing for six months and received a conditional criminal sentence for assault. In responding to a barrage of media attention, Cantona was asked whether it was important that players should set an example to youngsters. His reply was characteristically direct and controversial:

I think that one should stop treating the heart and soul of youngsters as clay to be modelled in whatever fashion you like. I am not there to educate anyone; I don't see that as my role. They should be able to work things out for themselves. Children go where they find sincerity and authenticity. In my way of working, of carrying out my career, I don't betray anybody and they know it. I don't consider that it would be better to teach them to deny their own emotions for the benefit of the established order. Is it in teaching people to be submissive that they become adult citizens? ${ }^{6}$

There is much here to ponder á la Derrida. It seems optimistic, at best, to think that kids "work things out for themselves" and that they "go where they find sincerity and authenticity." Indeed, the identity and antics of contemporary football celebrities do little to support such a claim. However, there is much that is good in

\footnotetext{
${ }^{6}$ Eric Cantona, My Philosophy, in NOT JuST A GAME 65 (S. Kelly ed., 1995).
} 
Cantona's views. Contrary to conventional views, education is often seen as an occasion to inculcate dominant values and ideas; it is less about opening up young people's minds than keeping them tightly shut. Although Cantona is not advocating that everyone should go around attacking and kicking everyone who says something that you do not like, he is stressing that obedience to Athe established order" is not always the best course of civic action. Of course, you have to be prepared to take the consequences of what you do and for what you believe, but the responsibilities of citizenship are best met by holding up society to its own cherished ideals, by pointing out any shortfall, and by sticking to your own principles when the going gets tough. In putting authenticity over submission, Cantona acted in a virtuous and honest way. Although many disagree with what he considered to be a defensible moral code, they should not contest his sense of honour. Cantona, like Socrates, deemed it important to be true to himself, almost whatever the consequences.

Similarly, Derrida made a principled, if ill-judged intervention in a festering incident which provided fuel to the self-righteous fire of his would-be detractors. In the late-Eighties, Derrida came to the defence of his long-time friend and teammate, Paul de Man. In 1988, five years after his death, the literary critic Paul de Man was outed as Nazi or, at least, as Nazi sympathiser. In particular, while living in Belgium, he had written a commissioned essay in 1940 for the pro-Nazi newspaper Le Soir. In it, de Man had observed that "one can thus see that a solution to the Jewish problem that would lead to the creation of a Jewish colony isolated from Europe would not have, for the literary life of the West, regrettable consequences." The Jewish Derrida stood by de Man and offered a deconstructive defence which was intended to demonstrate that de Man was not actually saying anything bad about the Jews. While Derrida's valorous act of friendship was commendable, his political discretion was lacking. For some, he seemed to expose the duplicitous quality of much deconstructive work by demonstrating how its interpretive techniques could be used almost at will to render the meaning of texts non-sensible and to defend the indefensible. However, for the less judgmental and ill-disposed, Derrida offered a gallant and very real act of loyalty which put his whole conventual reputation at risk for the sake of an important personal commitment. It was the legendary stuff of hermeneutical opacity and heroic naivety.

Beneath the theatrical snarls and Gallic shrugs, both Cantona and Derrida sought to embody an authentic responsibility to rebel against the very system that gave them their privileged and, in some quarters, adored status. In a world of convenient values and even more expedient justifications, they each took a stand which characterised as it threatened their whole legacy: they were prepared to be counted as more than deft performers and to stake their claims for a better world. Justice might always be deferred and elusive as a general virtue, but it could be 
established, however contingently and conditionally, by an impassioned blow against tyrannical resignation. While each may have acted rashly, they brought attention to the moral force of probity in a hypocritical world. And took a kick at it as an act of courage, not cowardice or complicity. Indeed, there was an authenticity to Cantona and Derrida that Camus would have admired, even if somewhat conditionally. They knew how they wanted to play the game in life and in football. Neither were prepared to play by others' rules -- victory was less important than integrity. Never beyond interpretation, Cantona's and Derrida's intervention were also interpretive gauntlets thrown down to the pusillanimous ranks of the chattering classes. They both left the game richer for their participation and more attuned to its own possibilities for renewal. Harnessing vision and inventiveness, they grasped that greatness was to be found in oneself, especially in the act of having the courage of one's convictions.

III.

For all the huff-and-puff of his lengthy career, Derrida knew that football, no matter how well or wonder-fully played can never attain that cherished independence from contingent considerations; what it means to play the game is destined to be born and die, flourish or perish in the hands of historical circumstance. However, like few before (or after him?), Derrida profoundly appreciated that and sought to impress its inevitable force on others. He grasped that the most important contribution that he could make was most definitely not to bring the competing games of life to a stop so that we can fix and settle upon what it means to play the game of LIFE for all time and in all places. Instead, he committed himself to inspiring all those who played with him or participated vicariously through him that the best way to play the game is to do so with abandon and commitment. If the accumulated performances of his career add up to anything, it is that life's challenge is not to bring the game to a close, but to keep it going with all the freshness and diversity that can be mustered. Matches and seasons end, players come and go - some more tragically than others -, but the game lives on, unending and unsullied in its possibilities to tease, to thrill and to redeem. It is sport as life and life as sport in which, as the old poem says, triumph and disaster impost forever.

In 1991, one fan of the beautiful game made a pessimistic assessment of football. He said that "in the world we live in, if you put it terms of a football game, the dark side is 3-0 up and it's half-time. I can't accept that this is the way it's gotta be." And Derrida assures us that it doesn't have to be. We must remember that we tend to get the world that we deserve as much as the world we want. However, we must also not forget that we can change that world; things only end up as they are not because it is meant to be that way, but because we have not yet got around to 
changing them. It is always half-time in that there is always at least another 45 minutes to play in which anything is possible, even if it does not always work out the way we hope it will or expect. But, sometimes, the dark side is vanquished. On a cold December Saturday in 1957, Charlton Athletic were down to 10 men and losing 5-1 against Huddersfield Town, with only 20 minutes left to play. Undaunted, Charlton battled back and pulled off one of the great comebacks of all time. Led by Johnny Summers' 5 goals, they went on to win the game 7-6. The example of that humble Charlton side should give hope to all of us. It is never over until it's over. And that's the case whether the fat lady has sung or not. Whether we like it or not and whether we choose to or not, there is no way not to be in the game of what it means to play the game. Jacques Derrida is a philosophical Johnny Summers for the ages. 
